\title{
STRIVING FOR SUPERIORITY TOKOH HARUMI TAKASUGI DALAM MANGA TAKASUGI SAN CHI NO OBENTOU KARYA NOZOMI YANAHARA (SEBUAH KAJIAN PSIKOLOGI SASTRA ALFRED ADLER)
}

\author{
Agustina Suryandari ${ }^{1 *}$, Redyanto Noor ${ }^{2}$, Nurdin Harry Kistanto ${ }^{3}$ \\ Fakultas IImu Budaya, Universitas Diponegoro, Indonesia ${ }^{123}$ \\ agustinasuryandari24@gmail.com ${ }^{1 *}$, redyanto@lecturer.undip.ac.id ${ }^{2}$, \\ nhkistanto@gmail.com ${ }^{3}$
}

\begin{abstract}
Struggle is one thing that must be continuously strived for success. The manga Takasugi san chi no Obentou by Nozomi Yanahara clearly shows the struggle of a young man named Harumi Takasugi to become the guardian of a minor. This study aims to find out how the process of Harumi Takasugi's struggle to become a responsible guardian in the manga Takasugi san Chi No Obentou by Nozomi Yanahara. This research is a qualitative research with a literary psychology approach, using the theory of Striving for Superiority proposed by Alfred Adler to show the beginning of a person's awakening from his sense of inferiority. The research data is taken from several scenes that show the process of Harumi Takasugi's struggle from being inferior to achieving superiority. The results of the study of the striving for superiority process show clearly that aggressiveness, self-motivation, positive thinking, self-sacrifice, and hard work make Harumi's character's striving for superiority the driving force for overcoming her feelings of inferiority and even satisfaction as the happiness Harumi feels in her life. Takasugi san Chi No Obentou manga by Nozomi Yanahara.
\end{abstract}

Keywords: process; struggle; inferiority; striving for superiority

\begin{abstract}
Abstrak
Perjuangan adalah satu hal yang harus terus diusahakan untuk memperoleh keberhasilan. Manga Takasugi san chi no Obentou karya Nozomi Yanahara dengan jelas menunjukkan proses perjuangan seorang perjaka bernama Harumi Takasugi untuk menjadi wali seorang anak di bawah umur. Penelitian ini bertujuan mengetahui bagaimana proses perjuangan tokoh Harumi Takasugi untuk menjadi wali yang bertanggung jawab dalam manga Takasugi san Chi No Obentou karya Nozomi Yanahara. Penelitian ini termasuk penelitian kualitatif dengan pendekatan psikoloi sastra, dengan memanfaatkan teori Striving for Superiority yang dikemukakan oleh Alfred Adler untuk menunjukkan awal kebangkitan seseorang dari rasa inferioritasnya. Data penelitian diambil dari beberapa adegan yang menunjukkan proses perjuangan tokoh Harumi Takasugi dari kondisi inferior sampai mencapai superioritasnya. Hasil penelitian proses striving for superiority menunjukkan dengan jelas bahwa keagresifan, motivasi diri, berpikir positif, rela berkorban, dan bekerja keras menjadikan striving for superiority yang dilakukan tokoh Harumi menjadi motor penggerak untuk mengalahkan perasaan inferiornya dan bahkan kepuasan menjadi kebahagiaan yang dirasakan tokoh Harumi di dalam manga Takasugi san Chi No Obentou karya Nozomi Yanahara.
\end{abstract}

Kata kunci: proses; perjuangan; inferiority; striving for superiority

\section{Pendahuluan}

Komik merupakan karya sastra bergambar (Bonnef, 1998:7). Komik berisikan susunan gambar dan kata-kata yang berisikan informasi yang ingin disampaikan kepada pembaca. Ruang gambar dan tata letak menjadi bagian yang sangat penting dalam komik untuk menggambarkan sebuah pesan. Komik juga dapat dipakai sebagai media penyimpan dan penyampai sebuah 
nilai-nilai kehidupan. Pada masa yang lalu muncul berbagai macam kritikan tentang komik. Komik dianggap karya yang tidak mendidik karena hanya berisikan gambargambar tentang kekerasan, tindakan brutal sehingga memberikan dampak negatif bagi moral pembaca terutama anak-anak (Muktiono, 2003:153). Seiring dengan berkembangnya waktu mulai muncul cerita-cerita komik yang dapat memberikan dampak positif bagi masyarakat, sehingga dapat mengembangkan daya imajinasi positif pada pembaca.

Manga adalah komik terbitan Jepang. Gambar pada manga biasanya berwarna hitam dan putih, meskipun ada juga manga yang colourfull. Ada banyak jenis manga di Jepang. Orang Jepang membuat klasifikasi manga sesuai gender dan usia pembaca. Ada jenis manga untuk pembaca anak laki-laki sampai usia 18 tahun dinamakan manga shounen biasanya berisikan topik yang dianggap menarik untuk anak laki-laki seperti robot, cerita laga petualangan yang heroik. Untuk pembaca manga remaja putra usia 18 sampai dengan usia 30 tahun ada jenis manga seinen. Konten manga ini biasanya berisikan cerita tentang laga petualangan yang sering melibatkan pahlawan pria, humor dagelan, dengan tema kehormatan. Sedangkan jenis manga seijin untuk orang dewasa biasanya mengacu pada manga pornografi yang menampilkan adegan seks secara eksplisit (Schodt, 1983:56). Jenis manga anak perempuan dan wanita usia muda dinamakan manga shojo yang berisikan pahlawan super wanita, bergenre romantis dan bertemakan cinta dengan narasi realisasi diri. Manga dengan judul Takasugi san chi no Obentou ini termasuk genre manga seinien, yang berisikan tentang seorang pemuda yang menjadi hero dalam cerita ini.

Manga ini ditulis oleh Nozomi Yanahara seorang penulis manga yang terkenal di Jepang. Nozomi Yanahara telah banyak menulis cerita manga sejak tahun 1994. Genre manga yang telah ditulis Nozomi Yanahara diantaranya 20 cerita manga shoujo, 9 cerita manga romance, 6 cerita manga historical, 3 cerita manga seinen, 2 cerita manga fantasy, 2 cerita manga supernatural, 1 cerita manga josei. Contoh beberapa manga karangan Nozomi Yanahara yang telah terbit, antara lain: Soushite Otogibanashi ni Naru jenis historical, jenis romance (1994), 1/10 no Naisho no Hanashi jenis historical (1996), Otenki no Miko jenis fantasy romance (2003), Rifujin no Mikata jenis Josei (2011), Koi wa Ronpa Dekinai jenis romance, seinen (2020).

Manga Takasugi san chi no obentou karya Nozomi Yanahara merupakan salah satu jenis manga seinen yang menceritakan tentang kehidupan seorang pemuda yang kedua orangtuanya meninggal sejak ia berusia 18 tahun. Nama pemuda ini Harumi Takasugi berusia 31 tahun, walaupun dia memiliki gelar doktor geografi tetapi ia belum memiliki pekerjaan tetap. Lamarannya untuk bekerja di tempat penelitian maupun sebagai dosen selalu mengalami penolakan. Di saat kondisinya di ujung tanduk tiba-tiba Harumi mendapat berita bahwa bibinya yang bernama Miya meninggal dunia. Miya meninggalkan surat wasiat yang isinya menunjuk Harumi keponakannya untuk mengasuh putrinya yang masih berusia 12 tahun. Ada tanggung jawab yang diberikan Miya kepada Harumi Takasugi. Bagi Harumi tanggung jawab ini sangat mustahil. Tiga belas tahun ia hidup sendirian sehingga lupa gambaran tentang keluarga. Hal ini menjadi poin kelemahan yang ada dalam diri tokoh Harumi Takasugi. Sisi Inferiority ini yang dimiliki tokoh Harumi Takasugi.

Namun demikian, striving for superiority menjadi bagian proses karakter yang ditunjukkan dalam diri tokoh Harumi 
Takasugi melalui cerita manga Takasugi san chi no Obentou karya Nozomi Yanahara dengan menggunakan poin-poin proses yang dikemukakan oleh Alferd Adler. Berdasarkan pandangan Adler, ditinjau dari sisi inferioritas, tujuan akhir dari pembentukan perkembangan psikologis adalah dorongan untuk menjadi survive sebagai usaha untuk mencapai superior.

Salah satu tulisan yang juga menggunakan teori milik Adler ini adalah sebuah skripsi berjudul "Kondisi Psikologis Karakter Utama Dalam Drama Ichi Rittoru no Namida; Kajian Psikologi" yang ditulis oleh Akmal Satriawaka (2018). Hasil dari penelitian tersebut menunjukkan adanya empat faktor penyebab tokoh utama memilih untuk terus maju dan melawan penyakitnya sendiri; untuk menjadi individu unggul yang memberikan pengaruh, tidak hanya kepada orang-orang di sekitarnya, tetapi juga orang-orang yang memiliki kondisi fisik yang sama. Faktorfaktor tersebut adalah 1) karakteristik dirinya sendiri; 2) keluarga dan temantemannya; 3) kompensasi dari kelemahannya sendiri; dan 4) tindakan mengabaikan pandangan negatif di sekitarnya (Satriawaka, 2018).

Sementara, persoalan yang dikaji dalam penelitian ini adalah inferiority tokoh Harumi sebagai perjuangan menuju kesuksesan individu dalam manga berjudul Takasugi san chi no Obentou.

\section{Metode Penelitian}

Penelitian ini merupakan penelitian kualitatif, yaitu yang mengolah dan menghasilkan data yang bersifat deskriptif (Endraswara, 2008:97-98). Sebagai data deskriptif, hasil yang diperoleh dalam penelitian kualitatif bukan hasil yang bisa dihitung atau dikalkulasi.

Penelitian ini menggunakan pendekatan psikologi sastra yang ditopang oleh tiga hal, yaitu: 1) pendekatan tekstual, mengkaji apek psikologi dalam karya sastra; 2) pendekatan reseptif-pragmatis, mengkaji aspek psikologi pembaca sebagai penikmat karya sastra yang terbentuk dari pengaruh karya sastra yang dibacanya serta proses resepsi pembaca sesuai dengan karya sastra yang dinikmati; dan 3) pendekatan ekspresif, mengkaji aspek psikologis penulis saat melakukan psoses kreatif yang terproyeksi melalui karya sastra yang dihasilkan, baik penulis sebagai individu/pribadi maupun sebagai bagian dari masyarakat.

Dalam kajian ini, yang menjadi objek material adalah komik berjudul Takasugi san chi no Obento karya Nozomi Yanahara. Oleh karena itu, maka teknik pengumpulan data yang digunakan adalah teknik kepustakaan. Teknik kepustakaan adalah teknik pengumpulan data tanpa menggunakan angka, tetapi data yang terkumpul berupa narasi, gambar, deskripsi yang berbentuk non angka (Purwandari, 2013).

Teori psikologi yang digunakan adalah milik Alfred Adler yang dikenal sebagai Individual Psychology (Psikologi Individu). Psikologi individu secara khusus mengkaji perbedaan antarindividu. Psikologi individual Adler merupakan suatu sistem psikologi yang bertujuan untuk memahami, mencegah, dan mengobati penyakit-penyakit mental (Naisaban, 2004:6).

Ada tujuh prinsip yang terkandung dalam teori Psikologi Individual Adler, yaitu: 1) Prinsip Rasa Rendah Diri (Inferiority Principle); 2) Prinsip Superior (Superiority Principle); 3) Prinsip Gaya Hidup (Style of Life Principle); 4) Prinsip Diri Kreatif (Creative Self Principle); 5) Prinsip Diri yang Sadar (Conscious Self Principle); 6) Prinsip Tujuan Semu (Fictional Goals Principle); dan 7) Prinsip Minat Sosial (Social Interest Principle). Dalam kajian ini tidak akan dibahas keseluruhan tujuh prinsip di atas, melainkan hanya perasaan 
inferiotas yang akhirnya membentuk prinsip superior dalam diri tokoh Harumi Takasugi dalam komik Takasugi san chi no Obentou karya Nozomi Yanahara.

\section{Hasil dan Pembahasan}

Adler (dalam Hall, 1993:243) berpendapat bahwa manusia pertama-tama adalah makhluk sosial yang bertanggung jawab. Adler juga memiliki keyakinan bahwa manusia adalah makhluk yang memiliki rasa interest yang sangat dalam dengan hal sosial. Adler memfokuskan penelitian pada kepribadian manusia. Tokoh Harumi Takasugi merupakan seorang pribadi dengan segala kompensasinya mau mengasuh sepupunya sendiri menjadi seorang wali. Formulasi teori Adler berpusat pada perilaku manusia. Perilaku manusia memperlihatkan sebuah metamorphosis sampai menjadi sebuah ide yang kompleks dan inklusif. Demikian yang terjadi dalam pribadi tokoh Harumi Takasugi adalah satu proses perubahan perilaku sehubungan dengan tindakan sosial yang diputuskan. Sebagai makhluk yang tidak sempurna selalu ada titik perasaan rendah diri atau inferiority yang dimiliki manusia.

$$
\text { Inferiority menurut Adler }
$$

berbentuk rasa malu, takut, dan rasa rendah diri sehubungan dengan kelemahan atau kekurangan yang dimiliki seseorang. Demikian pula tokoh Harumi Takasugi mengalami beberapa perasaan inferiority dalam Komik Takasugi san chi no Obentou karya Nozomi Yanahara. Pada gambar dalam adegan-adegan berikut ini menunjukkan perasaan inferiority yang mencengkeram tokoh Harumi Takasugi:

Perasaan inferiority tokoh Harumi Takasugi dialami pada saat dia harus menerima tanggung jawab untuk mengasuh sepupunya yang bernama Kururi. Harumi Takasugi adalah seorang pria lajang yang sama sekali tidak memiliki pengalaman apapun tentang keluarga. Bentuk inferiority pertama yang ada di dalam diri tokoh Harumi Takasugi terdapat dalam kutipan di bawah ini.

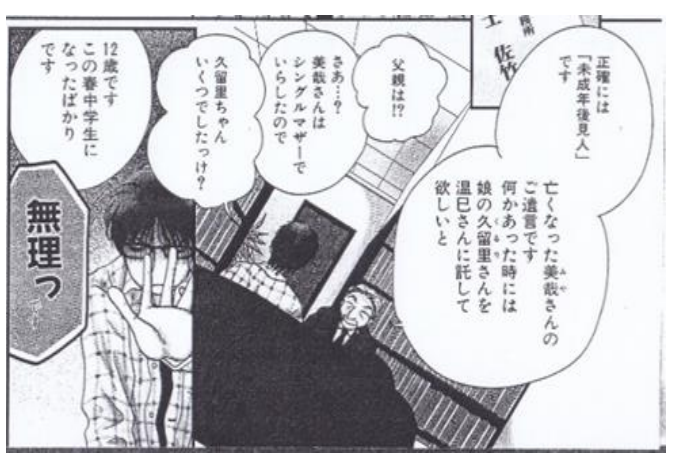

Gambar 1

佐竹：正確には【未成年後見人】で 亡くなった美歳さんの遺言です。 何があった時には娘のくるりさ んを温巳さんに託して欲しいと

Satake :(Tashika ni wa (miseinenkoukennin) desu. Nakunatta Miya san no yuigon desu. Nani ga atta toki niwa musume no Kururi san o Harumi san ni takashite hoshii to)

Lebih tepatnya anda akan bertindak sebagai wali anak yang masih di bawah umur. Ini surat wasiat dari Bu Miya. Tertulis kalau terjadi apa-apa padanya. Dia ingin putrinya Kururi diasuh oleh Pak Harumi.

温巳：父親は？!

Harumi : (Oya?!)

Ayahnya?

佐竹：さあ...? 美歳さんはシングル マザーでいらしたので。

Satake : (Saa...? Miya san wa singurumazaa de irashita node.)

Saya tidak tahu Bu Miya single mother, sih. 
温巳：久留里ちゃんいくつでしたっ け?

Harumi:(Kururi chan wa ikutsu deshitakke? )

Berapa usia Kururi?

佐竹 : 12 歳です。この春中学生にな ったばかりです。

Satake : (Nijuussai desu. Kono haruchuu gakusei ni nattta bakari desu.)

Duabelas tahun. Dia baru menjadi murid SMP di musim semi ini.

温巳 : 無理つです。

Harumi : (Muri desu...)

MUSTAHIL.....

Perasaan inferiority dapat dilihat melalui gambar 1. Perasaan lemah dan tidak mampu ditunjukkan melalui kata "MUSTAHIL" yang diucapkan oleh Harumi. Kata mustahil ini memiliki arti tidak mungkin atau di luar kemampuan. Bagi Harumi benar-benar sesuatu yang tidak mungkin dan di luar kemampuannya untuk menjadi wali bagi anak di bawah umur. Harumi sama sekali tidak memiliki pengalaman dalam mendidik anak karena masih lajang.

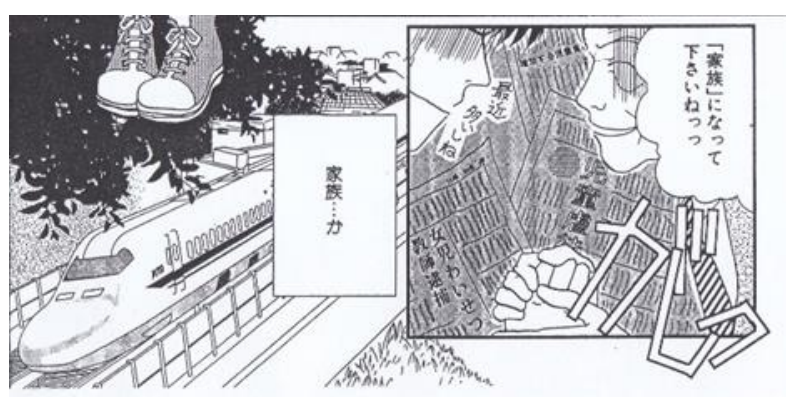

Gambar 2

佐竹：「家族」になってくださいね って

Satake : ((Kazoku) ni natte kudasainette.) Tolong jadi "keluarganya" ya?

温巳 : 家族...が
Harumi : Kazoku...ga

Keluarga, ya....

Pada adegan gambar 2 menunjukkan pada waktu Pak Satake meminta Harumi Takasugi untuk menjadi keluarga bagi Kururi. Pada point ini "keluarga" bagi Harumi merupakan satu hal menyentakkan jiwanya ditunjukkan dengan jawaban Harumi「家族... が」 (kazoku...ga) (keluarga ya) ungkapan ini membuat perasaan inferiority yang menunjukkan keraguan dalam hatinya mengenai gambaran keluarga yang sudah lama hilang dari benaknya.

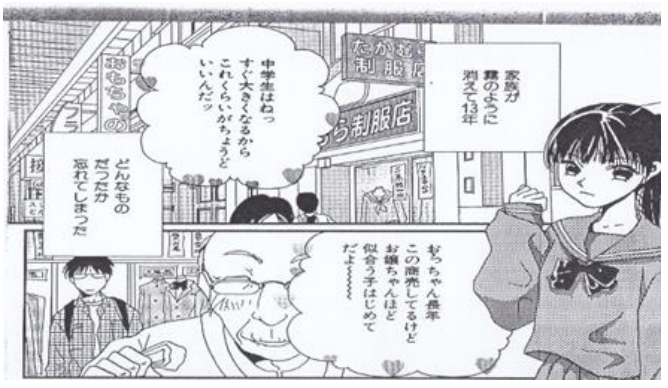

Gambar 3

温巳 : 家族が霞のように消えて 13 年。どんなものだつたか忘れて しまうだ。

Harumi: (Kazoku ga kasumi no you ni kiete 13 nen. Donna mono datsutaka wasurete shimauda.)

Sudah 13 tahun keluargaku hilang seperti kabut. Aku sudah lupa keluarga itu seperti apa.

Adegan pada gambar 3 menunjukkan mengapa ungkapan "keluarga" begitu menyentak hati Harumi dan menimbulkan perasaan inferiority dalam dirinya melalui gambar 5, menunjukkan bahwa sudah 13 tahun keluarga Harumi hilang seperti kabut. 13 tahun yang lalu ayah ibunya meninggal karena kecelakaan dan hanya beberapa bulan saja Harumi tinggal bersama Miya bibinya (ibu Kururi) setelah itu Miya 
bibinya pergi meninggalkannya. Sejak saat itu dia hidup sendirian. Hal inilah yang membuat Harumi mengalami perasaan rendah diri atau inferiority waktu mendengar kata keluarga. Perasaan rendah diri menguasainya karena dia sudah lupa tentang gambaran sebuah keluarga apalagi jika diminta mengasuh anak.

Pada adegan-adegan berikut ini mulai menunjukkan sikap dan upayaupaya Harumi Takasugi untuk melawan inferioritynya dengan melakukan striving for superiority. Striving for superiority merupakan awal dari kebangkitan seseorang dari rasa inferioritynya. Adanya kemajuan tindakan yang dikerjakan dan tidak hanya tinggal dalam kelemahan dan rasa rendah diri (inferiority).

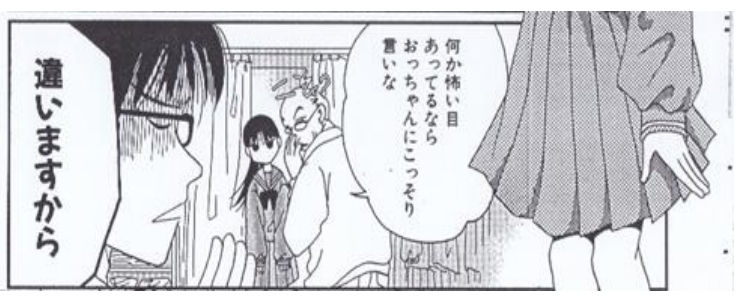

Gambar 4

佐竹：何か怖い目あってるならおつ ちゃんにこっそりいいな。

Satake: (Nanika kowai meatteru nara otchan ni kossori ii na.)

Kalau nona mengalami hal menakutkan, katakanlah diamdiam pada Paman, ya.

温巳：違いますから

Harumi : Chigaimasu kara. Anda salah sangka.

Pada adegan gambar 4 menunjukkan bahwa kekurangan yang yang dimiliki seseorang dapat membuat orang lain berprasangka buruk pada orang itu. Demikian juga yang dialami Harumi, melalui kekurangan yang ada di dalam diri Harumi membuat Pak Satake berprasangka negatif pada Harumi. Prasangka tersebut diungkapkan melalui pernyataan Pak Satake kepada Kururi yang mengatakan "Kalau nona mengalami ketakutan, katakan diam-diam pada Paman". Pernyataan tersebut menimbulkan perasaan inferiority bagi Harumi tetapi pernyataan Pak Satake juga mengguggah Harumi untuk melakukan striving for superiority yaitu usaha yang dilakukan untuk mengatasi inferiority (rendah diri) dari rasa kurang berharga pada dirinya agar menjadi pribadi yang superior.

Striving for superiority yang dilakukan Harumi adalah dengan membalas dan mengatakan「違います から」"anda salah sangka". Tindakan yang dilakukan melalui ungkapan ini, dinyatakan untuk mematahkan atau menangkis perkataan Pak Satake yang menaruh rasa curiga pada Harumi Takasugi, sebagai bentuk pembelaannya supaya orang lain (Pak Satake) tidak berpandangan yang salah dengannya.

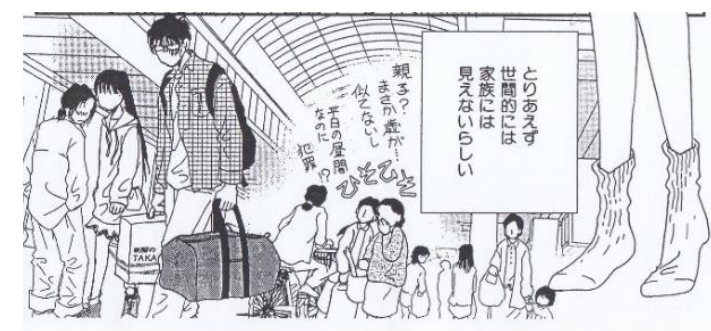

Gambar 5

温巳：とりあえず家族には世間的に は見えないらしい。

Harumi : (Toriaezu kazoku ni seaidateki ni mienai rashii)

Pokoknya dilihat dari pandangan masyarakat, sepertinya kami tak terlihat seperti keluarga

人々：親子?まさか歳が！似てない し。平日の昼間なの

Hitobito: (Oyako? Masaka sai ga ! Nite nai shi. Heijitsu no hiruma na noni keiji.) 
Ayah dan anak? Mustahil, usianya...lagian nggak mirip. Penjahat di siang bolong begini.

Adegan pada gambar 5 menunjukkan prasangka buruk masyarakat pada Harumi dan Kururi saat berjalan di stasiun. Orang-orang memandang Harumi dan Kururi tidak seperti keluarga. Mereka memandang dengan curiga dan melontarkan kata-kata yang cukup pedas. Orang-orang menganggap Harumi bukan seperti ayah dan anak melainkan seperti penjahat di siang bolong. Faktor dari luar yaitu kecaman, kecurigaan orang-orang di sekitar dapat menimbulkan perasaan inferiority yaitu rasa malu dalam diri Harumi. Melalui gambar ini ditunjukkan dengan bahasa tubuh Harumi yang berjalan sambil menunduk dengan raut muka memerah mendengar ocehan orangorang di sekitarnya.

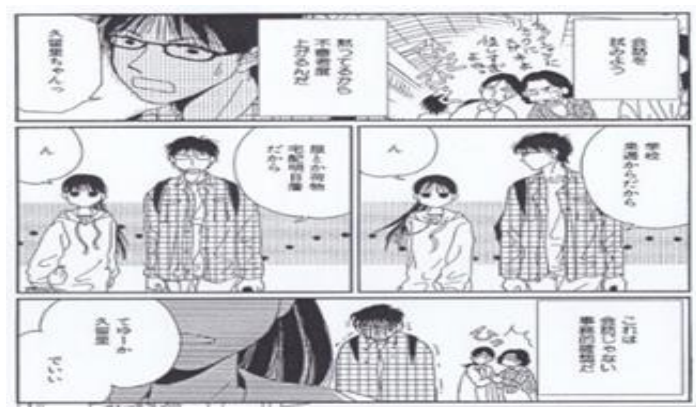

Gambar 6

人々 : チェックシャツにリュックに めがねよ。うたわがしすぎよね。

Hitobito: (Chekku shatsu ni ryukku ni meganeyo. Utawagashisugiyone.) Kemeja kotak-kotak pakai ransel dan kacamata terlalu mencurigakan.

温巳：会話をみよう。黙ってるから 不者度上がるんだ。久留里ちゃ んつ... 学 校来週だから。
Harumi : (Kaiwa o miyou. Damatteru kara fushado agaraunda. Kururichan... gakkou raishuu.dakara)

Akan kucoba memulai percakapan.Orang-orang jadi tambah curiga karena kami diam saja. Kururi chan...Sekolahnya mulai minggu depan?

久留: ん

Kururi : (n)

lya

温巳：服とか荷物宅配明日着だか ら

Harumi: (Fuku to nimotsu takuhai ashita chaku dakara.)

Seragam dan barang-barangmu akan sampai besok.

久留里: ん

Kururi : (n)

lya.

温巳：これは会話じやない事務的確 認だ。

Harumi: (Kore wa kaiwa janai jimuteki kakunin da.)

Ini sih, bukan percakapan tapi kayak konfirmasi soal pekerjaan.

Gambar 6 juga menunjukkan ungkapan perasaan curiga orang-orang di dalam kereta yang melihat Harumi dan Kururi. Faktor dari luar yang tidak mendukung bahkan melemahkan dan menimbulkan rasa inferiority seringkali dapat menjadi pendorong yang dapat membangkitkan semangat untuk melakukan hal positif. Demikian yang terjadi dalam diri Harumi faktor dari luar berupa pandangan curiga orang-orang sekitar menggugah hati Harumi untuk melakukan striving for superiority dengan cara mulai mengajak Kururi mengobrol, walaupun awalnya masih kaku seperti 
konfirmasi pekerjaan tetapi ini merupakan bentuk usaha yang dilakukan Harumi untuk menetralkan suasana.

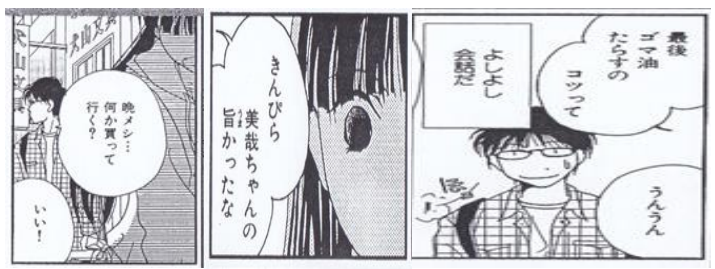

Gambar 7

温巳：晚メシ...何か買って行く?

Harumi : (Ban meshii nanika katte iku?) Mau beli sesuatu untuk makan malam?

久留里：いい!

Kururi : (ii !)

Tidak usah!

温巳：きんぴら美歳ちゃんの旨かっ たな。

Harumi: (Kinpira Miyachan no umakatta na.)

Kinpira buatan Miya enak ya.

久留里 :...最後ゴマ油たらすのコツって。 Kururi: (Saigo goma abura tarasu kotsutte.) Katanya poin pentingnya terakhir harus diberi minyak wijen.

\section{温巳：うんうん「よしよし会話 だ」。}

Harumi: (Un un (yoshi yoshi kaiwa).) Iya, iya ( Bagus ini percakapan).

Gambar 7 menunjukkan striving for superiority yang dilakukan Harumi melalui tindakan percakapan yang sudah lebih baik dengan mengambil topik pembicaraan tentang makanan yang sering dibuat Miya Ibu Kururi. Percakapan berjalan dengan natural sehingga memberi kepuasan dalam diri Harumi. Striving for superiority yang dikerjakan dengan agresif dan berulangulang akan membuat hasil yang lebih sempurna serta dapat memberi kepuasaan bagi pelaku yang mengerjakannnya.

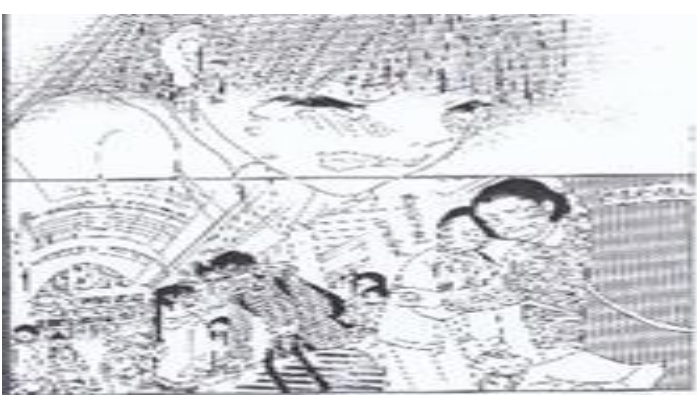

Gambar 8

Adegan pada gambar 8 menunjukkan ketika Harumi dan Kururi sedang membicarakan masakan buatan ibu Kururi, tiba-tiba Kururi menangis teringat ibunya yang baru saja meninggal. Hal tersebut menimbulkan lagi rasa curiga beberapa orang yang ada di situ kepada Harumi, mereka mengira Harumi menculik anak gadis. Orang-orang berteriak 「おま ゆりさん、こっちで」「Omayurisan、 kotchi de」(Polisi Patroli sebelah sini!). Kejadian ini kembali menimbulkan rasa inferiority pada Harumi berupa perasaan malu dan tertuduh.

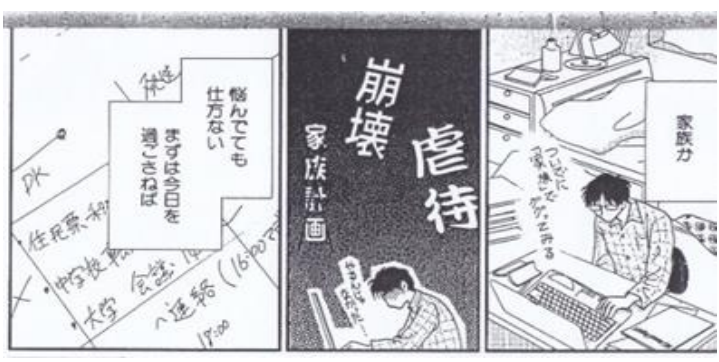

Gambar 9

温巳：「家族か」ついでに「家族」で ググてみる。虐待、崩壊、家族 計画「X」悩んでても仕方ない。 まずは今日過ごさぬば

Hirumi :((Kazokuka) tsuide ni (Kazoku) de gugute miru. Gyakutai, houkai, 
kazoku keikaku (X). Nayande temo shikata nai. Mazu wa kyou sugosanuba.)

Sekalian kucari tentang "keluarga" pakai google. Yang ada hanya penganiayaan, kehancuran sedangkan rencana keluarga tidak ada. Bingung pun percuma. Pokoknya aku harus bisa melewati satu hari ini dulu.

Adegan pada gambar 9 menunjukkan Harumi tidak patah semangat walaupun mengalami perasaan inferiority. Perasaan ini memicu Harumi untuk melakukan striving for superiority. Tindakan yang dilakukam Harumi rela bangun tengah malam untuk mencari info tentang keluarga melalui google. Tetapi yang ditemukan di google hanya berita tentang penganiayaan keluarga, kehancuran keluarga, rencana mengenai keluarga tidak ditemukan. Sepertinya usahanya sia-sia tetapi Harumi terus berusaha berjuang untuk bisa melalui hari demi hari dengan satu tekad. Striving for superiority yang dilakukan yaitu memotivasi diri sendiri dengan bertekad berjuang melewati hari lepas hari.

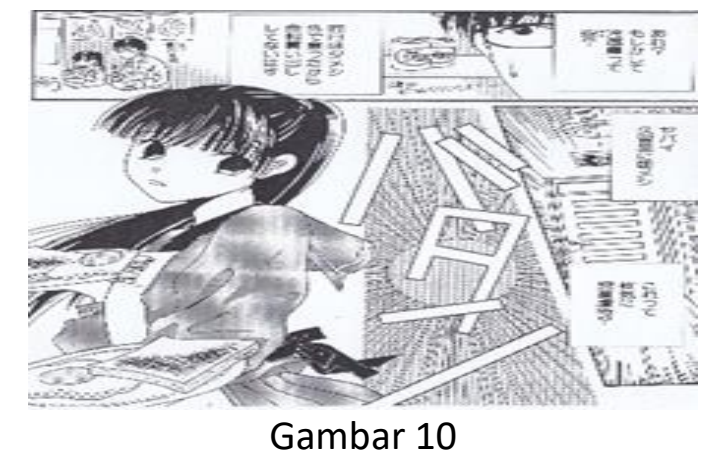

温巳：あれ?もしかして冷蔵庫って 穴?昨日はゆめし外で食つたか ら食料買い出ししてないはずや はい、久留里朝めし。これつて 何気に育児虐待?

Harumi: (Are? Moshikashite reizoukotte ana? Kinou wa yumeshi soto de shokutsu takara shokuryou kaidashi shite nai hazu. Yahai, Kururi asa meshi. Koretsute nanige ni ikuji gyakutai.)

Lho? Kalau nggak salah kulkasku kosong? Kemarin malam setelah makan di luar, kami tak belanja bahan makanan.

Adegan pada gambar 10 menunjukan bahwa Harumi lupa melakukan tanggung jawabnya sebagai seorang wali anak. Harumi lupa belum mengisi kulkasnya dengan bahan makanan yang dibutuhkan untuk bekal pagi hari bagi Kururi.

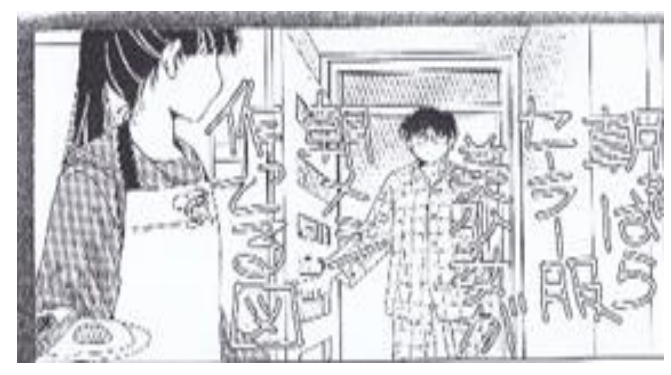

Gambar 11

朝っぱらセーラー服美少女が朝メシ作 って図。(Asappara seeraa fuku bishoujo ga asameshi tsukutteru zu.) Adegan pagi-pagi gadis cantik berseragam sailor sedang membuatkan sarapan.

$$
\text { Adegan pada gambar } 11
$$
menampilkan Harumi yang benar-benar terkejut pagi-pagi melihat Kururi sudah bangun dan membuat sarapan. Rasa inferiority kembali mencengkeram diri Harumi, perasaan malu kembali menguasainya karena dia bangun lebih siang dan tidak menyiapkan makan pagi bagi Kururi. Harumi tidak melakukan tanggung jawabnya dengan baik sebagai seorang wali. 


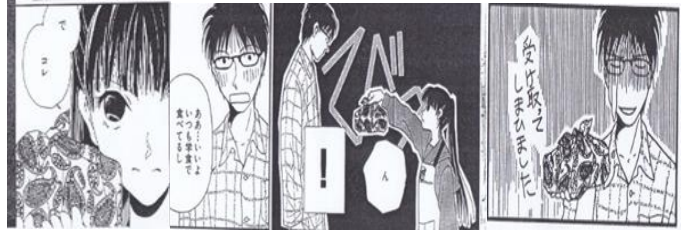

Gambar 12

久留里：でこれ。

Kururi : (De, kore).

Kemudian ini.

温巳 : ああ...いいよ。いつも学食で 食べてるし

Harumi: (Aa,..iiyo. Itsumo gakushoku de tabeteru shi)

Aah aku tak apa-apa kok. Biasanya aku makan di kantin kampus

久留里：世話になるし、作るし、これ 力ら

Kururi : (Sewa ni naru shi,tsukuru shi, korekara.)

Aku sudah merepotkan, oleh karena itu akan kubuat bekal mulai sekarang.

温巳：受け取ってしまひました。

Harumi: (Uketotte shimahimashita.)

(Akhirnya aku terima juga.

Adegan pada gambar 12 menunjukan inferiority pada Harumi dalam bentuk rasa malu yang semakin bertambah saat Kururi memberikan bekal makanan yang dibuat sendiri oleh Kururi untuk dibawa Harumi ke tempat bekerja. Seolah-olah Harumi tidak berfungsi sebagai seorang wali yang bertanggung jawab.

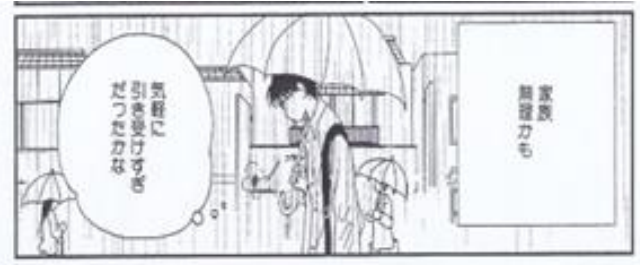

Gambar 13
温巳 : 家族無理かも、気軽に引き受 けすぎだつたかな。

Harumi: (Kazoku muri kamo, kikei hikiukesugi datsuta ka na.)

Sepertinya keluarga mustahil untukku, mungkin aku terlalu menggampangkan saat menerima tugas ini).

Adegan pada gambar 13 menunjukkan bahwa Harumi benar-benar terpukul dan ia merasa tidak mampu dan tidak berdaya. la merasa keputusannya untuk menjadi seorang wali anak merupakan suatu hal yang keliru. Rasa inferiority kembali menguasai dirinya.

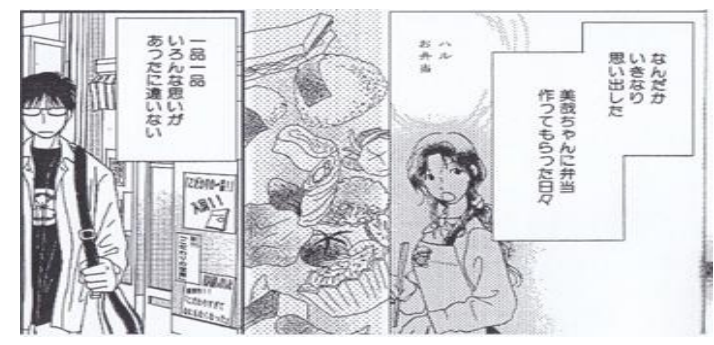

Gambar 14

温巳:なんだかいきなり思い出した。 美歳ちゃんに弁当作ってもらっ た日々。

Harumi: (Nandaka ikinari omoidashita. Miyachan ni bentou tsukutemo moratta hibi.)

Tiba-tiba aku teringat, hari-hari saat Miya membuatkan bekal untukku.

美歳：温巳、お弁当

Miya :(Harumi, obentou.) Harumi, bekalnya.

温巳 : 一品一品いろんな思いがあつ たに違いない

Miya : (Ippin-ippin ironna omoi ga atta ni chigainai.)

Satu per satu makanan itu mempunyai kenangan tersendiri. 
Adegan pada gambar 14 menunjukan Harumi yang tiba-tiba teringat dengan Miya yang selalu membuatkan bekal makanan untuknya. Kenangan ini membangkitkan semangat Harumi untuk melakukan striving for superiority. Kenangan ini memotivasi Harumi untuk bangkit dari perasaan inferiority yang mencengkeramnya, dalam hal ini bentuk striving for superiority yang dilakukan adalah memotivasi diri sendiri.

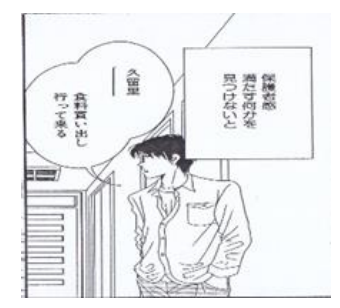

Gambar 15

温巳：保護者感満たす何かを見つけ ないと。久留里食料買い出し行 って来る。

Harumi: (Hogoshakan michitasu nanika o mitsukenaito. Kururi shokuryou kaidashi ittekuru.)

Aku harus berbuat sesuatu seperti layaknya seorang wali. Kururi, aku mau pergi belanja bahan makanan.

Adegan pada gambar 15 menunjukkan striving for superiority yang dilakukan Harumi muncul dari motivasi di dalam dirinya yang membangkitkan semangatnya untuk melakukan tindakan sebagai seorang wali yang bertanggung jawab. Hal yang dilakukannya yaitu dengan berencana hendak pergi berbelanja bahan makanan.

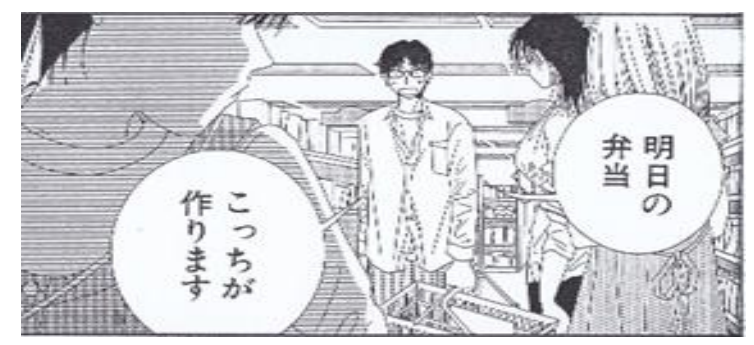

Gambar 16

温巳：明日の弁当, こっちが作りま す。

Harumi: (Ashita no bentou, Kotchi ga tsukurimasu.)

Bekal besok, biar aku yang buat.

Gambar 16 menunjukkan striving for superiority yang dilakukan Harumi dengan mengatakan kepada Kururi bahwa besok ia akan membuatkan bekal untuk Kururi.

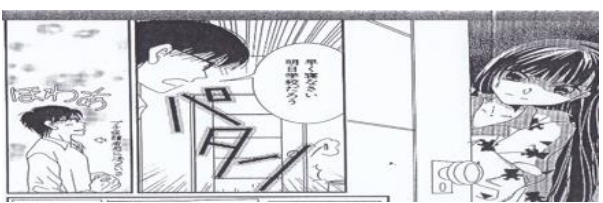

Gambar 17

温巳 : 早く寝なさい。明日学校だろう

Harumi: (Hayaku nenasai. Ashita gakkou darou.)

Cepat tidur, besok sekolah, kan?.

$$
\text { 「パターン」(Pataan..blam) }
$$

suara pintu ditutup

温巳 : ほわあ...やっと保護者感にし てる。

Harumi: (Howaa...yatto hogoshakan ni shiteru.)

Senangnya sudah sedikit bertindak seperti wali.

Adegan pada gambar 17 menunjukkan Harumi yang melakukan tindakan sebagai seorang wali yang bertanggung jawab dengan memberi perintah kepada Kururi untuk cepat tidur. Dalam hal ini striving for superiority yang dilakukan sebagai salah satu bentuk rasa tanggung jawabnya sebagai seorang wali. Dialog selanjutnya merupakan ungkapan yang menunjukkan kepuasan hati Harumi sebagai hasil dari tindakan striving for superiority. 


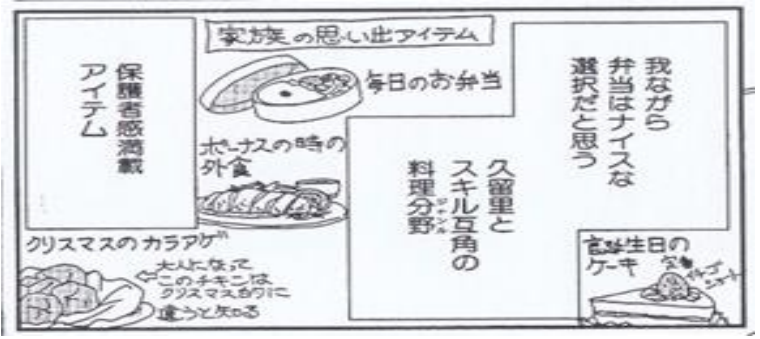

Gambar 18

温巳：我ながら弁当はナイスな選択 だと思う。久留里とスキル互角 の料理分野。保護者感満アイテ 么。

Harumi: (Wa nagara bentou wa naisu na sentaku da to omou. Kururi to sukiru gokaku bunya Hogoshakan ..... aitemu.)

Kurasa membuatkan bekal adalah pilihan bagus. Kemampuan memasakku dan Kururi sama. Jadi ini hal yang pas supaya aku bisa bertindak layaknya seorang wali.

Adegan pada gambar 18 menunjukkan Harumi yang memotivasi dirinya sendiri dengan memutuskan untuk membuat bekal di pagi hari sebagai pilihan terbaik seorang wali. Hal ini adalah bentuk striving for superiority yang dilakukan Harumi.

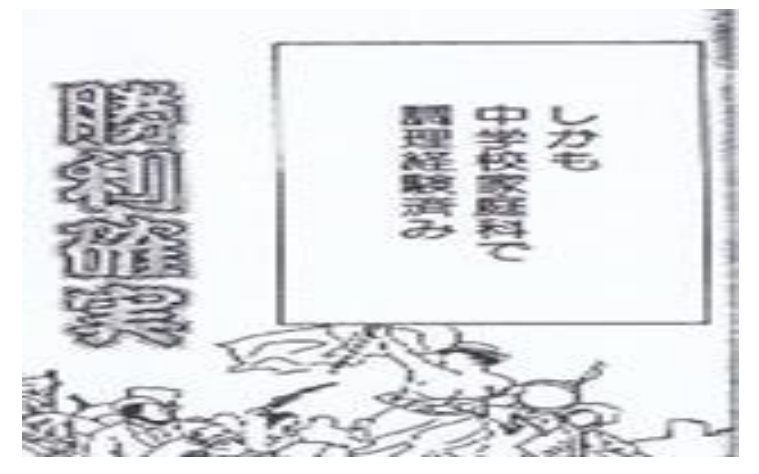

Gambar 19

温巳：しかも中学校家庭料で調理経 験済み。勝利確実...
Harumi: (Shikamo chuugakkou kateiryou de chouri keikenshuumi. SHOURIKAKUJITSU...)

Aku juga pernah belajar memasak di pelajaran kerajinan rumah tangga. KEMENANGAN SUDAH DIPASTIKAN...

Adegan pada gambar 19 menunjukkan pikiran positif yang ada pada Harumi. la teringat bahwa ia pernah belajar memasak di pelajaran kerajinan rumah tangga sehingga dengan modal tersebut ia yakin bisa berhasil melaksanakan salah satu tanggung jawabnya sebagai seorang wali. Dalam hal ini, bentuk striving for superiority yang digunakan oleh Harumi adalah dengan cara menunjukkan pada pikiran positif yang dimiliki Harumi, melalui ungkapan 「勝利確実」「SHOURIKAKUJITSU」 (Kemenangan sudah dipastikan). Ungkapan ini menyatakan satu pikiran positif yang memotivasi Harumi bahwa dia akan berhasil memasak.

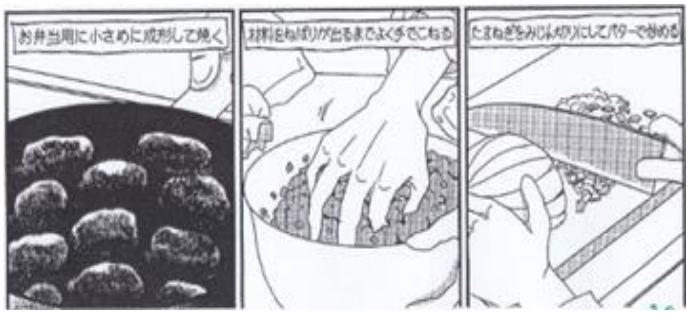

Gambar 20

温巳 :玉ねぎをみじん切りにしてバタ 一で始め。材料をねばりが出る までよく手でこねる。お弁当用 に小さめに形式して焼く。

Harumi : (Tamanegi o mijin kiri ni shite bataa de hajimeru. Zairyou o nebari ga deru made yoku te de koneru. Obentouyou ni kosame ni keishiki shite yaku.)

Cincang bawang bombay, tumis dengan mentega. Campur bahan- 
bahan dengan tangan sampai tidak lengket. Dibentuk kecil untuk bekal lalu panggang.

Gambar 20 menunjukkan striving for superiority yang dilakukan Harumi berupa suatu usaha atau tindakan Harumi dengan mulai membuat bekal dengan mencincang bawang bombay dan menumis serta mencampur semua bahan serta dibentuk kecil untuk bekal dan memanggangnya. Bekal yang dibuat Harumi kepada Kururi yaitu HANBURG (hanburger).

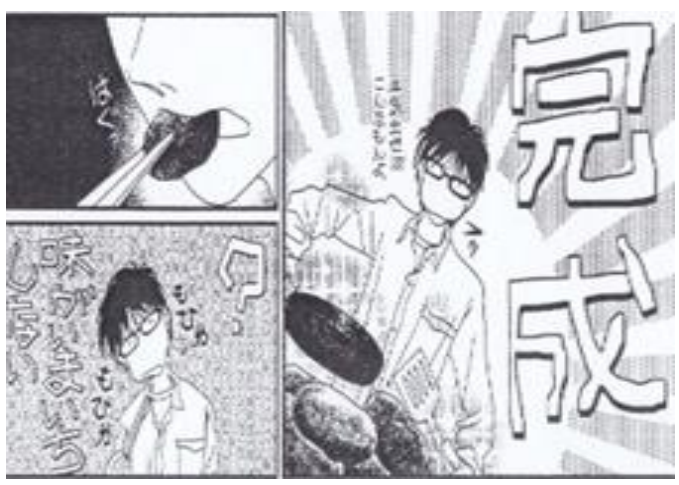

\section{Gambar 21}

温巳：完成. . . 本気出せば こんなもんよ。

(KANSEI..Honkidaseba

konna mon yo.)

SELESAI.. beginilah kalau aku serius.

温巳 $\quad \begin{aligned} & \text { : もひゅ...もひゅ } \\ & \text { がいまいちしない。... 味 }\end{aligned}$

Harumi : (Mohyu...mohyu.. Aji ga ima ichi shinai.)

Nyam..nyam.. Rasanya hambar

Adegan pada gambar 21 menunjukkan rasa inferiority yang kembali memenuhi diri Harumi saat mengetahui bahwa hasil masakan terasa hambar dia merasa tidak berhasil.

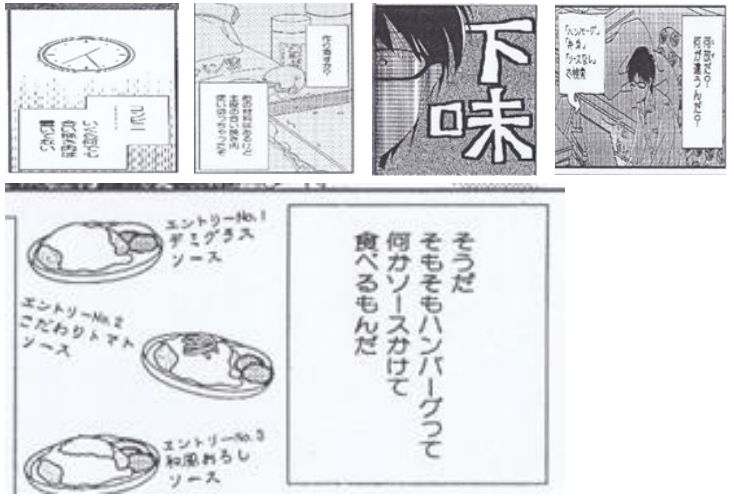

Gambar 22

温巳：そうだ。そもそもハンバーガ 一グって、何かソースかけて食 ベるもんだ。いや、でも美哉ち やんの弁当ハンバーグには何も かかってなかった。なぜだ? 何 が違うんだ「ハンバーグ」「弁 当」「ソースなし」で倹索。下 味。作り直すか? ほかの材料は あるけど、主役の合い挽き肉使 い切ちゃったぞ。コンビニ ...W くら何でも合い挽き肉は置いて ない。

Harumi: (Souda. Somo somo hanbaaguutte, nanika soosu kakete taberunda. Iya, demo Miya chan no bentou hanbaagu ni wa nani mo kakatte nakatta. Shitaaji. Tsukuri naosuka. Hoka no zairyou wa aru kedo, shuyaku no ai hikiniku tsukaitsu chattazo. Konbini..ikura nandemo aihikiniku wa oite nai.)

Oh, iya. Hanburg biasanya dimakan dengan saus. Tapi bekal buatan Miya tidak ada sausnya, kok. Kenapa? apa yang salah? Mencari dengan kata kunci "hanburg" "bekal" "tanpa saus". BUMBU. Bikin ulang? Bahan lain masih ada, tapi daging cincangnya sudah habis. Minimarket nggak mungkin ada daging cincang tersisa. (sudah pukul setengah 2 pagi). 
Gambar 22 menampilkan semangat Harumi yang kembali muncul melalui sikap striving for superiority. Harumi tidak menyerah meskipun ia harus mengulang membuat hanburg sekali lagi meskipun jam sudah menunjukkan pukul setengah 2 pagi. Harumi tetap berusaha untuk membuat hanburg dengan rasa seperti buatan Miya ibu Kururi walaupun harus dengan pengorbanan. Sikap ini menunjukkan striving for superiority yang dilakukan Harumi.

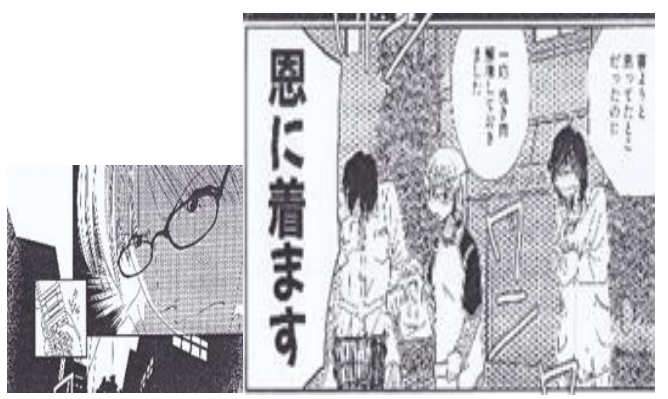

Gambar 23

温巳，その晚金香山さんにでんわをかけ る。 (Harumi, sono ban Kayama san ni denwa o kakemashita.)

Harumi malam itu menelpon Kanayama.

香山：ねようとおもつてたこだった のに。

Kayama: (Neyouto omotteta kodatta noni.) Padahal kami sudah mau tidur.

小坂 : 一応挽き肉解凍しておきまし た。

Kosaka : (Ichiou hikiniku kaitou shite okimashita.)

Es di dagingnya sudah kucairkan sekalian.

温巳 : 恩に着ます。

Harumi: (On ni tsukimasu.) AKU BERUTANG PADA KALIAN.
Adegan pada gambar 23 menunjukkan tindakan Harumi yang tidak mau menyerah. Dia berusaha menelpon Kayama pada malam itu juga untuk meminta daging cincang karena di minimarket daging cincang sudah habis. Hal ini merupakan bentuk striving for superiority yang dilakukan Harumi.

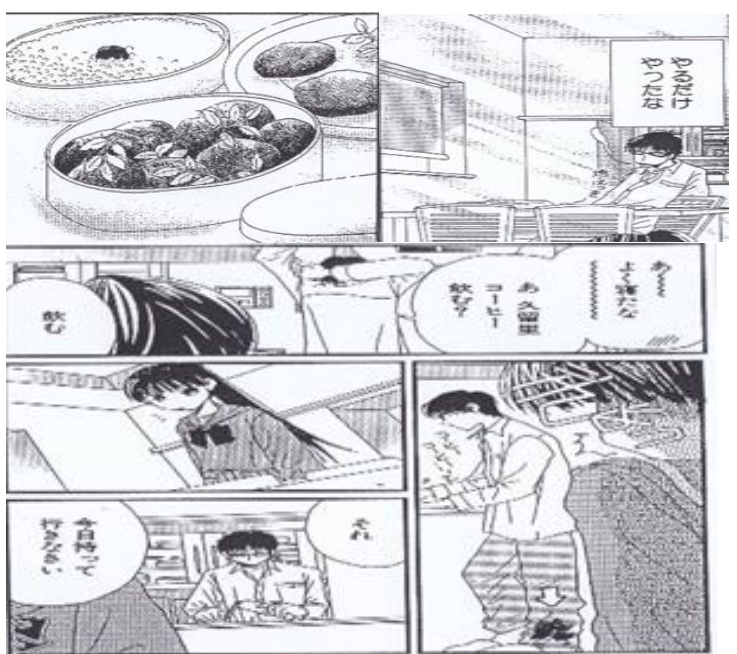

Gambar 24

温巳 : やるだけやったな。

Harumi: (Yaru dake yatta na.)

Aku sudah melakukan semua yang kubisa.

温巳 : あ...よく寝たな。あ、久留里コ 一ヒ一飲む?

Harumi: (A... yoku neta na. A, Kururi koohii nomu?

久留里：飲む。(Nomu.)

Mau

温巳：それ、今日待って行きなさい。 Harumi: (Sore, kyou matte ikinasai.) Itu bekal hari ini bawalah.

Adegan pada gambar 24 menunjukkan striving for superiority berhasil dikerjakan. Harumi telah selesai membuat hanburg Dia sudah melakukan semua yang bisa dilakukan untuk Kururi. 
Sebagai seorang wali dia tetap terus melakukan striving for superiority dengan melakukan tindakan melayani Kururi seperti membuatkan kopi serta membawakan bekal makanan untuk Kururi, meskipun tidurnya hanya sebentar saja tetapi tugas sebagai seorang wali telah dilakukan oleh Harumi.

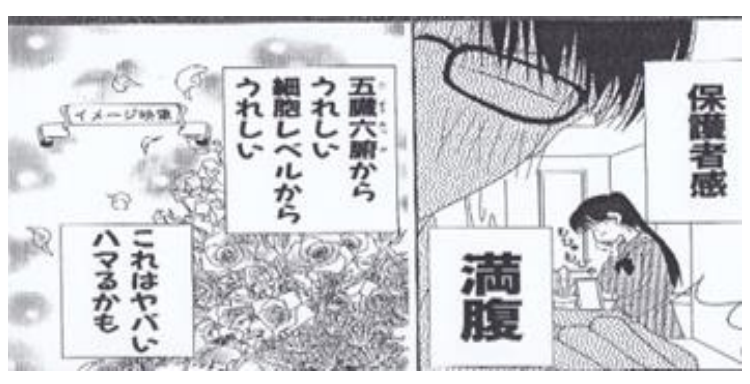

Gambar 25

温巳：保護者感... 満腹

Harumi : (Hogoshakan... Manpuku..) PERASAANKU SEBAGAI WALI TERPUASKAN.

温巳：五臓六腑からうれしい。細胞 レベルからうれしい。これはヤ バいハマるかも。.

Harumi : (Gozou roppu kara ureshii. Saibou reberu kara ureshii. Kore wa yabai hamaru kamo.)

Organ-organku bergembira aku senang sampai ke sel-selku. Ini gawat aku bisa ketagihan.

Gambar 25 menunjukkan hasil yang diperoleh waktu striving for superiority terus dilakukan dan terus diusahakan dengan agresif menimbulkan kepuasan bagi pelakunya dan rasa ketagihan untuk terus melakukan striving for superiority.

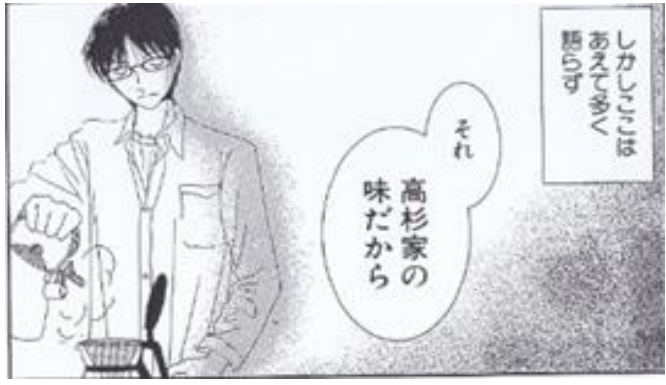

Gambar 26

温巳：しかしここはあえて多く語 ず。 それ高杉家の味だから。

Harumi: (Shikashi koko wa aete ooku katarazu.Sore Takasugiya no aji dakara.)

Tapi di sini aku tak boleh bicara berlebihan. Itu rasa keluarga Takasugi.

Adegan pada gambar 26 menunjukkan hasil perjuangan striving for superiority yang terus menerus dikerjakan dengan agresif oleh Harumi. Pada akhirnya Harumi menemukan bentuk dan suasana keluarga Harumi Takasugi yang memiliki ciri khas tersendiri.

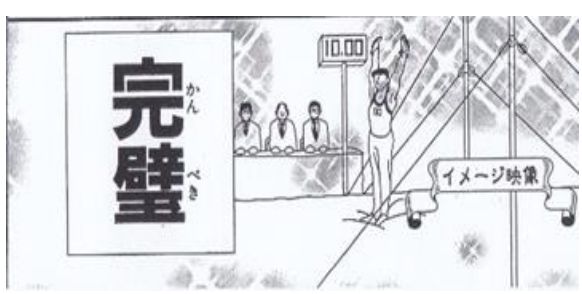

Gambar 27

\section{完壁 KANBEKI SEMPURNA}

Adegan pada gambar 27 ditampilkan seperti atlet yang selesai bertanding dan akhirnya mengalami kemenangan melalui proses striving for superiority yang terus menerus Harumi lakukan sehingga mencapai superior atau kesempurnaan yang diungkapkan melalui pernyataan 「完 壁」「KANBEKI」(SEMPURNA) 


\section{Simpulan}

Manusia merupakan makhluk yang harus bersikap agresif untuk memperoleh hasil dan agar bisa survive. Untuk meninggalkan perasaan rendah diri hanya dibutuhkan satu dorongan untuk menjadi superior melalui sikap striving superiority yang harus terus menerus dilakukan. Superior di sini bukan untuk bersaing dengan orang lain, melainkan untuk mencapai superioritas di dalam diri sendiri.

Kehidupan manusia digerakkan oleh dinamika perilaku individu itu sendiri untuk mencapai superioritas atau kesempurnaan. Memotivasi diri sendiri dan berpikir positif menjadi salah satu faktor yang sangat penting untuk mendorong keberhasilan striving for superiority seperti yang dilakukan oleh Harumi tokoh dalam manga Takasugi san Chi no Obentou karya Nozomi Yanahara. Harumi tidak menyerah pada rasa inferioritynya tetapi terus berusaha dan membayar harga dengan berusaha keras sehingga menghasilkan kepuasan sebagai hasil dari kerja keras yang dia lakukan sebagai seorang wali yang bertanggung jawab dan dapat mencapai model keluarga Takasugi yang unik.

\section{Referensi}

Adler, A. (1990). Journal of Humanistic Phsychology. United Kingdom: Sage Publication.

Alex, Sobur. (2003), Psikologi Umum, Bandung: Pustaka Setia.

Aminudin. (2009). Pengantar Apresiasi Karya Sastra. Bandung: Sinar Baru Agesindo.

Boneff, Marcel. (1998). Komik Indonesia. Jakarta: KPG bekerjasama dengan forum Jakarta-Paris.
Endraswara, Suwardi. (2008). Metode Penelitian Sastra. Jogjakarta: Pustaka Widya Utama.

Hurlock, E.B. (1978). Child Development (6th ed). New York: McGraw-Hill

Indah, Nurochman, Setiarini. (2016). The Superiority in Christian Grey in The Fifty Shades. Jurnal IImiah Sastra Volume 4. No 1.

Moleong, Lexy.J. (2000), Metodologi Penelitian Kualitatif. Bandung: PT. Remaja Rusdyakarta.

Nelson, Andrew. (2005). Kamus Kanji Modern Jepang-Indonesia. Jakarta: Kesaint Blanc.

Nurgiyantoro, B. (2010), Teori Pengkajian Fiksi, Yogyakarta: Gajah Mada University Press.

Satriawaka, A. (2018). "Kondisi Psikologis Karakter Utama Dalam Drama Ichi Rittoru no Namida; Kajian Psikologi". Skripsi. Universitas Diponegoro. Retrieved from http://eprints.undip.ac.id/68092/

Schodt, Frederick L. (1983). Manga! Manga! The World of Japanese Comics. England: The Blekpnad Press of Harvard University.

Schilling, Mark. (1997), The Encylopedia of Japanese Pop Culture, New York: Weatherhill.

Suryabrata, Sumadi. 2002. Psikologi Kepribadian. Jakarta: PT Raja Grafindo Persada.

Purwandari, EK. (2013). Pendekatan Kualitatif untuk Penelitian Perilaku Manusia. Sarana Pengukuran dan Pendidikan Psikologi (PPSP3). Universitas Indonesia, Depok, Indonesia.

Yanahara, Nozomi. 2014. Takasugi san chi no Obentou. Toukyouto: Kadokawa Kaisha 